\title{
Nitrite scavenging activity and anti-inflammatory effects of standardized Cirsium setidens extract
}

\author{
Hee-Yeon Kwon, Sun-Il Choi, Bong-Yeon Cho, Seung-Hyun Choi, Wan-Sup Sim, \\ Han Xionggao, Gill-Woong Jang, Ok-Hwan Lee* \\ Department of Food Science and Biotechnology, Kangwon National University, Chuncheon 24341, Korea
}

\section{표준화된 고려엉겅퀴 추출물의 아질산염 소거능 및 항염증효과}

\author{
권희연 · 최선일 · 조봉연 · 최승현 · 심완섭 · 한웅호·장길웅 · 이옥환* \\ 강원대학교 바이오산업공학부 식품생명공학과
}

\begin{abstract}
The purpose of this study was to determine nitrite scavenging activity and the anti-inflammatory effect of Cirsium setidens ( $C$. setidens), which is perennial herb belonging to the Compositae family that is found mainly in Gangwon province, Korea. We studied nitrite scavenging ability, cell viability, nitric oxide production, and inflammatory-related gene expression in lipopolysaccharide (LPS)-treated RAW 264.7 macrophages. Our results indicated that $C$. setidens extract increased the nitrite scavenging ability in a dose-dependent manner. In order to determine the cytotoxicity and the concentration range of $C$. setidens extract suitable for treating RAW 264.7 cells, the XTT assay was performed. $C$. setidens extract did not have any cytotoxic effect at contractions of 50,100 and $200 \mu \mathrm{g} / \mathrm{mL}$ and the absorbance values were $103.30 \pm 9.61,99,98 \pm 12.99$ and $101.15 \pm 11.49 \%$, respectively. Also, $C$. setidens extract decreased the nitric oxide production of RAW 264.7 cells in a dose-pendent manner. In order to determine whether $C$. setidens extract inhibits inflammation-related factors, such as COX-2, iNOS, IL-6 and TNF-a. In RAW 264.7 cells treated with $C$. setidens extract, COX-2, iNOS, IL-6 and TNF-a levels were decreased to 55, 84, 83 and 77\%, respectively. Based on these results, $C$. setidens was revealed to have anti-inflammatory effect to be potentially material in functional food.
\end{abstract}

Key words : $C$. setidens Nakai, nitrite scavenging ability, anti-inflammation, RAW 264.7 cell, LPS

\section{서 론}

다양한 육제품과 수산가공품 등에 발색제로 첨가되는 질산염과 아질산염은 제품의 발색 및 육색의 안정화에 기여 할 뿐만 아니라 제품의 질을 저하시킬 수 있는 미생물에 대한 정균작용을 하며, 육제품의 보수성과 결착성을 증진 시키는데 중요한 역할을 한다(1). 이러한 질산염은 소화기 관 내에서나 식품의 저장 중에 질산염 환원세균과 질산환원

*Corresponding author. E-mail : loh99@kangwon.ac.kr Phone : 82-33-250-6454, Fax : 82-33-259-5565

Received 25 January 2019; Revised 25 February 2019; Accepted 13 March 2019.

Copyright (c) The Korean Society of Food Preservation. All rights reserved.
효소에 의하여 아질산염으로 환원되며, 이 아질산염은 2 급 및 3급 amine류와 반응하여 발암물질인 nitrosoamine을 생 성하는 것으로 알려져 있다(2). 또한, 아질산염 자체로도 과량 섭취 시 독성을 나타내어 methemoglobin증과 같은 각종 중독 증상을 유발한다고 알려져있다(3).

Nitric oxide(NO)는 반응성이 높은 생성분자로써, L-arginine으로부터 nitric oxide synthase(NOS)에 의해 생성 된다. $\mathrm{NO}$ 는 혈관의 이완, 신경전달 및 세포 내 면역반응에 관여하는데, 특히 대식세포가 lipopolysaccharide(LPS)에 의 해 자극될 때 inducible NOS(iNOS)가 발현되어 많은 양의 $\mathrm{NO}$ 를 생성하게 된다. 이렇게 생성된 많은 양의 $\mathrm{NO}$ 는 박테 리아, 바이러스, 균류 및 기생충과 같은 병원균에 대응하기 위한 염증반응에서 매우 중요한 매개물질의 역할을 한다 (4). 하지만 염증과정에서의 과도한 NO 생성은 염증반응을 
촉진 시킬 뿐만 아니라 염증관련 생합성을 촉진하고 염증을 심화시켜 조직의 손상, 유전자 변이 및 신경손상 등을 일으 켜 류마티스성 관절염과 자가 면역 질환 등의 염증성 질환 의 발병을 초래할 수 있다. 따라서, NO 생산의 저해는 항염 증제 개발의 주요 목표이기도 하다(5,6). Nitric oxide synthase(NOS)에는 neuronla NOS(nNOS), endothelial NOS(eNOS), inducible NOS(iNOS) 세 가지가 존재한다. $\mathrm{nNOS}$ 와 $\mathrm{eNOS}$ 는 세포 내에 항상 존재하지만, $\mathrm{iNOS}$ 는 일부 세포에서 LPS, cytokines 및 박테리아 독소 같은 자극들에 노출되는 경우에만 발현이 되며 NOS 중 가장 많은 양의 $\mathrm{NO}$ 를 생성한다 $(7,8)$. Cyclooxygenase(COX)는 arachidonic acid를 이용하여 prostaglandins을 생성하는 효소로 COX-1 과 COX-2 두 가지로 존재하며, 다양한 세포에서 각각 다른 발현 정도를 나타낸다. $\mathrm{COX}-1$ 은 정상적인 생체기능에서 발현되지만, COX-2는 염증반응 부위에서 주로 발현이 된 다. COX-2에 의해 생성되는 Prostaglandin E2(PGE2)는 통 증, 발열에 관여하는 염증 매개체로서 염증반응과 면역반 응에 관여하고 혈관신생을 촉진시키는 등 암 발생에도 중요 한 역할을 하는 것으로 알려져 있다(9). TNF-a와 IL-6는 대식세포를 활성화시키고 다양한 염증관련 cytokine들의 발현을 증가시켜서 염증반응을 일으키는데 중요한 역할을 한다(10).

고려엉겅퀴(Cirsium setidens)는 주로 강원도에서 발견되 는 국화과의 다년생 초본으로 한방에서 여러 용도의 약재로 사용되어 왔으며, 봄에 돋아나는 연한 어린잎과 부드러운 줄기는 살짝 데쳐서 나물 및 국으로 섭취하며, 줄기와 껍질 등은 튀김, 무침, 볶음, 데침 등으로 요리하며 특유의 향미를 느낄 수 있는 차로도 이용된다(11). 예로부터 고려엉겅퀴는 한방에서는 지상부 또는 지하부를 약용으로 많이 이용하였 으며, 지상부는 개화기에 베고 뿌리는 가을철에 채취하고 말려 경혈, 지혈, 소종의 효능이 있어 간염 및 고혈압 등의 치료에 사용한다고 보고된 바 있다(12). 이에 따라 고려엉겅 퀴는 기능적 건강 유지 및 질병 예방 식품으로 많은 주목을 받고 있으며, 최근 Kim과 Chung(13)의 연구에서 고려엉겅 퀴가 알코올에 의한 지방간 발생 및 관련된 간 손상을 유의 적으로 억제할 수 있음을 확인하였고, Cho 등(14)의 연구에 서는 고려엉겅퀴 추출물이 지방세포 분화과정 및 ROS의 생성을 억제하는 항비만 효능을 가진 것을 확인하는 등 다양한 연구가 활발히 진행되고 있는 식물 중 하나이다.

건강기능식품의 개발에 있어서 천연물질에 대한 안정성 과 기능성을 입증해야하며 원료에 대한 표준화가 필요하 다. 표준화란 천연물질이 함유하는 고유한 성분의 변성을 최소화하여 제품이 일정한 품질이 유지되도록 원료의 생산 에서부터 제조 과정까지의 모든 기술과 정보를 관리하는 것을 말하며, 지표성분은 기능성 원료의 기능성이 일정하 게 유지되는 것을 확인할 수 있는 지표이므로 정밀하고 신뢰성 있는 분석방법을 사용하여야 한다(15).
이에 본 연구는 고려엉겅퀴 추출물의 아질산염 소거능 실험과 항염증 활성을 조사하기 위하여 LPS로 자극된 RAW 264.7 세포에서 세포가 방출하는 NO 생성량과 pro-inflammatory cytokine인 iNOS, COX-2, IL-6, TNF-a의 생성량의 변화를 조사하여 고려엉겅퀴의 아질산염 소거능 과 항염증 효과 유무와 정도를 알아보고자 수행되었다.

\section{재료 및 방법}

\section{실험재료 및 시약}

본 연구에 사용한 표준화된 고려엉겅퀴(Cirsium setidens Nakai) 시료는 (주하티(Hongcheon, Korea)로부터 제 공받아 사용하였다. (주하티에서는 원료 표준화를 위하여 추출용 매, 추출시간, 산지 및 수확시기별 지표성분의 함량을 비교 분석하였으며, 강원대학교에서 (주하티가 제 공한 추출물에 대하여 항비만 활성을 in vitro 수준에서 평가하여 지표성분 함량과 항비만 효능 결과를 바탕으로 최적의 추출조건을 확립하였다 $(14,16,17)$. 표준화된 시료를 제조한 공정은 다 음과 같다. 원재료의 25 배의 $40 \%$ ethanol을 가하여 $70^{\circ} \mathrm{C}$ 에 서 2시간 가압 순환추출 후, 60-100 mesh에서 여과를 거치 고, $60^{\circ} \mathrm{C}$ 이하에서 $-0.8 \mathrm{kG}$ 감압농축하여 $-40^{\circ} \mathrm{C}$ 에서 $48-72$ 시 간 동결건조한 시료를 $80 \mathrm{mesh}$ 로 분쇄하였다. 그 후, 제공받 은 시료를 일정 농도로 희석하여 실험에 사용하였다.

Dulbecco's modified Eagle's medium (DMEM), penicillinstreptomycin (P/S), fetal bovine serum (FBS), trypsin-EDTA 및 phosphate-buffered saline (PBS)는 Gibco (Gaithersburg, $\mathrm{MD}, \mathrm{USA}$ )로부터 구입하여 사용하였다. Dimethyl sulfoxide (DMSO)는 Junsei Chemical (Tokyo, Japan)에서 구입하여 사용하였다.

\section{아질산염 소거능 측정}

아질산염 소거능은 Kato 등(18)의 방법을 변형하여 측정 하였다. 추출물 $1 \mathrm{~mL}$ 에 $\mathrm{NaNO}_{2}$ 용액 $1 \mathrm{~mL}$ 을 가하고 0.1 $\mathrm{M} \mathrm{HCl}$ 을 가하여 $\mathrm{pH}$ 를 1.2 로 조정한 후 $\mathrm{DW}$ 로 총량을 10 $\mathrm{mL}$ 로 만든 후 $37^{\circ} \mathrm{C}$ 에서 1 시간 반응시켰다. 반응액 $1 \mathrm{~mL}$ 을 취하여 $2 \%$ acetic acid $5 \mathrm{~mL}$, Griess 시약(1\% sulfanilic acid : $1 \%$ naphthylamine=1:1) $0.4 \mathrm{~mL}$ 을 가하여 잘 혼합한 후 실온에서 15 분 동안 반응시키고 $520 \mathrm{~nm}$ 에서 흡광도를 측정 하였다. 공시험은 Griess 시약 대신 증류수를 $0.4 \mathrm{~mL}$ 을 가하 여 동일하게 행하였고 다음과 같은 계산식을 사용하여 계산 하였다.

Nitrate scavenging ability(\%) $=\left[1-\left(A_{\text {Experiment }} / A_{\text {Control }}\right)\right] \times 100$

$$
\begin{aligned}
& \mathrm{A}_{\text {Experiment }} \text { : 시료군 흡광도 } \\
& \mathrm{A}_{\text {Control }} \text { : 대조군 흡광도 }
\end{aligned}
$$




\section{세포배양}

RAW 264.7 대식세포는 American Type Culture Collection (ATCC, Rockwille, MD, USA)에서 구입하여 실험에 사용하 였다. $10 \% \mathrm{FBS}, 1 \% \mathrm{P} / \mathrm{S}$ 가 함유된 $\mathrm{DMEM}$ 배지에서 $\mathrm{CO}_{2}$ incubator (MCO-20AIC, Sanyo, Osaka, Japan) $\left(37^{\circ} \mathrm{C}, 5 \%\right.$ $\mathrm{CO}_{2}$ )에서 배양되어 각 실험에 사용하였다.

\section{세포독성평가}

RAW 264.7 대식세포에 대한 고려엉겅퀴 추출물의 세포 독성평가는 $\mathrm{Kim}$ 등(19)의 방법에 따라 XTT\{2,3-bis (2-methoxy-4-nitro-5-sulfophenyl)-2H-tetrazolium-5-carbox anilide innersalt $\}$ assay kit를 이용하여 측정하였다. 세포를 $1 \times 10^{5}$ cell $/ \mathrm{mL}$ 로 96 well plate에 분주하고 고려엉겅퀴 추출 물을 농도별 $(50,100,200 \mu \mathrm{g} / \mathrm{mL})$ 로 처리 후 24시간 배양시 킨 후 XTT 시약을 첨가한 후 $\mathrm{CO}_{2}$ incubator (MCO-20AIC, Sanyo, Osaka, Japan) 에서 4시간 반응시켜 microplate reader (Spectramax i3, Molecular Devices, Sunnyvale, CA, USA)를 사용하여 $450,690 \mathrm{~nm}$ 에서 흡광도 값을 측정하여 값을 빼준 후 다음 식으로 계산하였다.

$$
\text { Cell viability }(\%)=\left(A_{\text {Experiment }} / A_{\text {Control }}\right) \times 100(\%)
$$

\section{Nitirc Oxide (NO) 생성능 평가}

$\mathrm{NO}$ 생성능 평가는 $\mathrm{Bae}$ 등(20)의 방법을 수정하여 측정하 였다. 세포 배양액의 $\mathrm{NO}$ 함량은 sodium nitrite $\left(\mathrm{NaNO}_{2}\right)$ 로 표준곡선을 그려 계산에 사용하였다. 세포를 $1 \times 10^{5} \mathrm{cell} / \mathrm{mL}$ 로 96 well plate에 분주하고 $0.1 \mu \mathrm{g} / \mathrm{mL}$ LPS가 첨가된 배지에 $1 \mu \mathrm{M}$ indomethacin과 농도별 고려엉겅퀴 추출물 $(50,100$, $200 \mu \mathrm{g} / \mathrm{mL}$ )을 각각 처리한 후 $37^{\circ} \mathrm{C}, 5 \% \quad \mathrm{CO}_{2}$ incubator (MCO-20AIC, Sanyo, Osaka, Japan)에서 24시간 배양시킨 후 배양액 $100 \mu \mathrm{L}$ 를 다른 96 well plate에 옮긴 후 Griess reagents $(0.1 \%$ NEDHC (N-1-(naphthyl)-ethylene diamide; sulfanilanide in $\left.5 \% \mathrm{H}_{3} \mathrm{PO}_{4}\right) 100 \mu \mathrm{L}$ 을 새롭게 옮긴 배양액과 섞어준 후 실온에서 10 분간 반응시켜 $550 \mathrm{~nm}$ 에서 흡광도를 측정하였다.

\section{$\mathrm{RT}-\mathrm{PCR}$ 분석}

세포를 $1 \times 10^{5} \mathrm{cell} / \mathrm{mL}$ 로 $100 \mathrm{pi}$ dish에 분주하고 $0.1 \mu \mathrm{g} / \mathrm{mL}$
의 Lipopolysaccharide (LPS)가 첨가된 배지에 $1 \mu \mathrm{M}$ indomethacin, $40 \mathrm{mM}$ 5-Aminoimidazole-4-carboxamide ribonucleotide (AICAR), 농도별 고려엉겅퀴 추출물(50, $100,200 \mu \mathrm{g} / \mathrm{mL}$ )을 각각 처리한 후 $37^{\circ} \mathrm{C}, 5 \% \mathrm{CO}_{2}$ incubator (MCO-20AIC, Sanyo, Osaka, Japan)에서 24시간 배양시켰 다. 그 후 PBS로 2회 세척 후 TRIzolTM Reagent $1 \mathrm{~mL}$ 첨가하 여 harvest 후 RNA 추출 후, 역전사중합효소(reverse transcriptase)를 이용하여 complementary DNA(cDNA)를 만 들고 합성된 $\mathrm{cDNA}$ 와 primer로 RT-PCR $\left(\mathrm{C} 1000^{\mathrm{TM}}\right.$ Thermal Cycler, Bio-Rad, Foster City, CA, USA)을 이용하여 유전자 의 발현 정도를 측정하였다. RT-PCR 결과물은 $2 \%$ 한천 (agarose) 겔에서 전기영동 후 UV에서 증폭된 DNA band를 Carestream MI SE 프로그램(Carestream Health Inc., Rochester, NY, USA)을 이용하여 band intensity로 수치화하 여 나타내었다. 실험에 사용한 primer sequence는 Table 1과 같다.

\section{통계처리}

아질산염 소거능 측정, XTT assay, NO 생성능 평가, RT-PCR은 SAS version 9.4 (SAS institute Inc., Cary, NC, USA)을 이용하여 분석하였다. 유의성 분석은 one-way ANOVA 검정을 실시하여 유의성은 $\mathrm{p}<0.05$ 수준에서 검정 하였다.

\section{결과 및 고찰}

\section{아질산염 소거능 측정}

아질산염 소거능 측정은 Griess 시약의 sulfanilamide와 $\mathrm{N}$-1-naphylethylenediamine dihydrochloride가 $\mathrm{NO}_{2}$ 와 반응 하여 azo 화합물을 형성하게 되는데, 이 azo 화합물의 흡광 도를 측정하는 방법이다. 고려엉겅퀴 추출물을 이용하여 아질산염 소거능을 측정한 실험 결과는 Fig. 1과 같다. 양성 대조군으로 사용한 $\mathrm{BHA}$ 의 경우 $6.25,12.5,25 \mathrm{mg} / \mathrm{mL}$ 의 농도에서 $42.27,71.92,81.04 \%$ 의 값을 나타내어 농도 유의 적으로 소거능이 증가하는 것을 확인할 수 있었다. 고려엉 겅퀴 추출물 또한 마찬가지로 $6.25,12.5,25 \mathrm{mg} / \mathrm{mL}$ 의 농도 에서 $21.17,49.58,68.33 \%$ 의 값을 나타내어 양성대조군과

Table 1. Primer sequences for RT-PCR analysis.

\begin{tabular}{ccc}
\hline \multirow{2}{*}{ Primers } & & Sequences \\
\cline { 2 - 3 } & Forward & Reverse \\
\hline B-actin & ATGGATGACGATATCGCTGC & GCTGGAAGGTGGACAGTGAG \\
iNOS & CCCTTCCGAAGTTTCTGGCAGCAGC & GGCTGTCAGAGCCTCGTGGCTTTGG \\
COX-2 & CACTACATCCTGACCCACTT & ATGCTCCTGCTTGAGTATGT \\
TNF- $a$ & TTGACCTCAGCGCTGAGTTG & CCTGTAGCCCACGTCGTAGC \\
IL-6 & GTACTCCAGAAGACCAGAGG & TGCTGGTGACAACCACGGCC \\
\hline
\end{tabular}


같이 농도 유의적으로 소거능이 증가함을 확인할 수 있었 다. Kim 등(21)의 연구에서 아질산염은 식육제품, 수산가공 품 등에 독소생성억제, 발색 및 산패 방지의 효과를 위하여 첨가되는 것으로 과도하게 섭취할 시 독성을 나타내어 methemoglobin증과 같은 각종 중독 증상을 유발한다고 보 고된 바 있다. 따라서 본 연구에서 고려엉겅퀴 추출물의 아질산염 소거능을 측정한 결과, 고려엉겅퀴 추출물이 생 체 내에서도 효과적인 아질산염 소거작용을 통해 nitrosoamine 생성을 억제하는 아질산염 소거제로서 이용될 수 있을 것으로 사료된다.

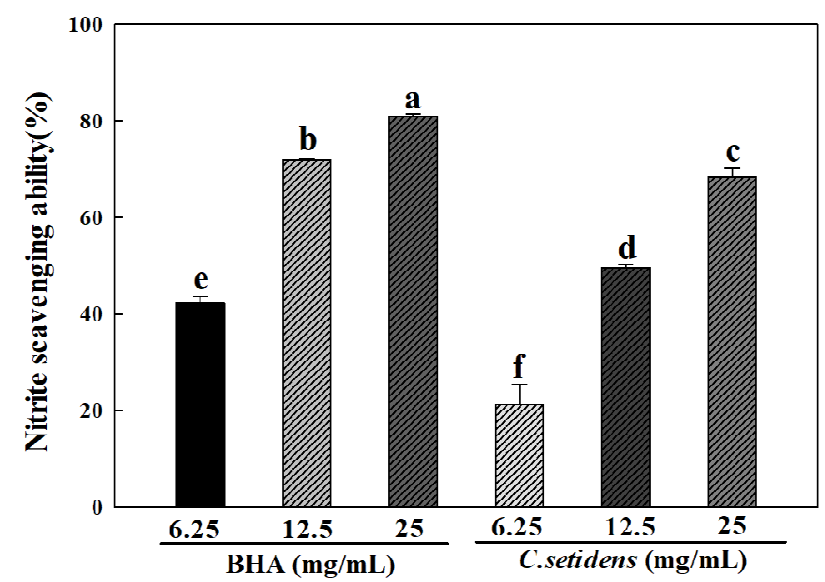

Fig. 1. Nitrite scavenging ability of $C$. setidens extract and BHA. BHA:Butylated hydroxyanisole.

Each value represents mean $\pm \mathrm{SD}(\mathrm{n}=3)$. ${ }^{\text {af }}$ Means with different letters are significantly different at $\mathrm{p}<0.05$ by Duncan's multiple range test.

\section{$\mathrm{XTT}$ 세포독성평가}

XTT 세포독성평가는 XTT와 PMS(phenazine methosulfate)

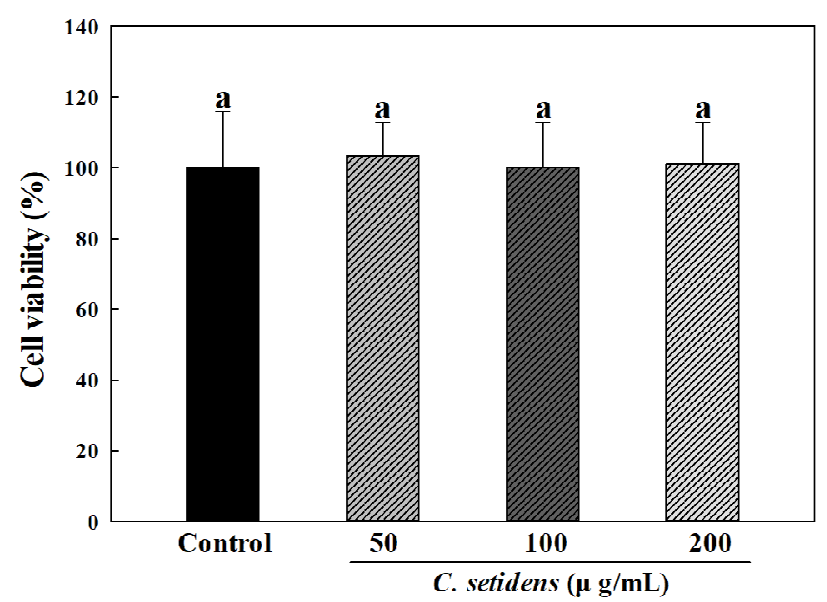

Fig. 2. Effects of $C$. setidens extract on cell viability of RAW 264.7 cells.

Cell viability was measured by XTT assay. Cells were treated with $50-200 \mu \mathrm{g} / \mathrm{mL}$ of $C$. setidens extract for $24 \mathrm{~h}$.

Each value represents mean $\pm \mathrm{SD}(\mathrm{n}=3) .{ }^{\text {af }}$ Means with different letters are significantly different at $p<0.05$ by Duncan's multiple range test.
를 섞은 시약을 세포 배양액에 첨가하게 되면 살아있는 세포 내 미토콘드리아의 탈수소효소에 의하여 XTT의 tetrazolium 링구조가 분해되어 노란색 formazan crystal을 형성하게 되는데, 이 노란색의 흡광도를 측정하는 원리이 다. 고려엉겅퀴 추출물의 XTT 세포독성평가 실험 결과는 Fig. 2 와 같다. $50,100,200 \mathrm{\mu g} / \mathrm{mL}$ 의 농도에서 고려엉겅퀴의 세포독성평가를 진행한 결과 모두 control군과 비슷한 흡광 도 값을 나타내어 $50,100,200 \mu \mathrm{g} / \mathrm{mL}$ 의 농도 모두에서 독성이 없는 것을 확인하였다.

\section{$\mathrm{NO}$ 생성능 평가}

$\mathrm{NO}$ 생성능 평가는 대식세포의 대사산물인 nitrate $\left(\mathrm{NO}_{3}{ }^{-}\right)$ 와 nitrite $\left(\mathrm{NO}_{2}\right)^{-}$의 생성농도를 확인할 수 있으며 이를 Griess reaction을 통해 확인한다. 질산환원효소를 이용하여 $\mathrm{NO}_{3}^{-}$ 를 $\mathrm{NO}_{2}{ }^{-}$로 환원 시키고 Griess 시약을 이용한 발색반응으로 $\mathrm{NO}_{2}^{-}$의 농도를 측정할 수 있다(22). LPS를 이용하여 자극을 준 RAW 264.7 대식세포에서의 고려엉겅퀴 추출물의 NO 생성능 실험 결과는 Fig. 3과 같다. 세포만 배양한 실험군에 서 $\mathrm{NO}$ 의 농도는 $5.17 \pm 0.13 \mu \mathrm{M}$ 로 매우 낮게 측정이 되었고, LPS만 처리한 실험군에서의 $\mathrm{NO}$ 의 농도는 $71.45 \pm 1.67 \mu \mathrm{M}$ 로 통계적으로 대조군과 유의성을 보이며 증가하였다. 양 성대조군으로 쓰인 indomethacin $1 \mu \mathrm{M}$ 을 처리한 군의 경우 $47.26 \pm 4.22 \mu \mathrm{M}$ 로 NO 생성량이 LPS만 처리한 군에 비해 많이 감소한 것을 확인할 수 있었다. $50,100,200 \mu \mathrm{g} / \mathrm{mL}$ 농도의 고려엉겅퀴 추출물을 첨가한 실험군에서의 $\mathrm{NO}$ 농 도는 각각 $65.01 \pm 1.52 \mu \mathrm{M}, 58.33 \pm 1.29 \mu \mathrm{M}, 51.74 \pm 2.58 \mu \mathrm{M}$ 로 측정되어 농도 유의적으로 $\mathrm{NO}$ 생성이 억제되는 것을 확인할 수 있었다. Soe 등(23)의 연구에서는 NO가 감염부위 의 활성화된 대식세포에서 면역조절, 혈관확장, 신경전달

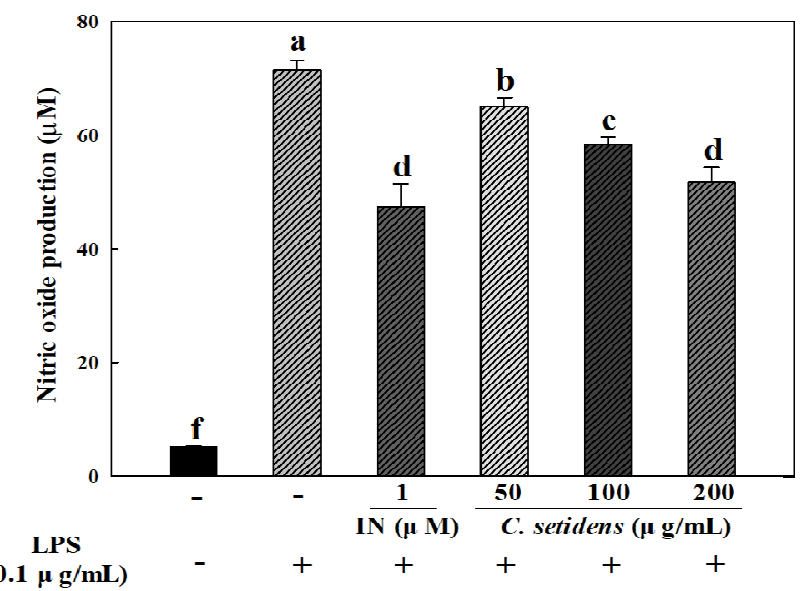

Fig. 3. Effect of $C$. setidens extract on LPS-Induced NO production in RAW 264.7 Cells.

IN:indomethacin.

The cells were treated with $1 \mu \mathrm{M}$ indomethacin, $50-200 \mu \mathrm{g} / \mathrm{mL}$ of $C$. setidens extract and $0.1 \mathrm{\mu g} / \mathrm{mL}$ LPS for $24 \mathrm{~h}$. The amounts of NO were determined by Griess assay. Each value represents mean $\pm \mathrm{SD}(\mathrm{n}=3)$. ${ }^{\mathrm{f}} \mathrm{f}$ Means with different letters are significantly different at $p<0.05$ by Duncan's multiple range test. 
등의 역할이 있다고 보고한 바 있으며, Kim 등(24)의 연구에 서 $\mathrm{NO}$ 는 지속적인 염증의 진행에 의한 종양형성촉진, 면역 반응촉진 등 여러 생물학적 반응에 관여하는 인자로 보고된 바 있다. 따라서 고려엉겅퀴 추출물의 NO 생성 억제능은 면역반응을 조절하여 염증관련 질환을 효과적으로 개선할 수 있을 것으로 사료된다.

\section{RT-PCR을 이용한 Pro-inflammatory cytokine 분석}

$\mathrm{COX}-2$ 는 염증관련 cytokine, 세균성 내독소, 자외선 등과 같은 여러 종류의 염증 매개체에 의해 발현되어 염증반응뿐 만 아니라 각종 퇴행성 질환의 발병에 중요한 역할을 하는 것으로 알려져 있다(25).

iNOS는 평소에는 세포 내에 존재하지 않으나 한 번 발현 되면 오랜 시간 동안 다량의 $\mathrm{NO}$ 를 생성하며, 이때 생성된 $\mathrm{NO}$ 가 염증매개체의 생합성을 촉진시켜 염증 반응을 촉진
시켜 염증을 심화시키는 것으로 알려져 있다(26,27).

IL-6는 림프구를 활성화시켜 항체의 생산을 증가시키는 cytokine으로 IL-6의 발현은 염증반응에서 항상 증가되고 있는 것으로 보고되고 있다(28).

TNF- $a$ 가 인간의 염증성 피부질환과 관련이 있음은 이미 많이 보고되어지고 있으며, 정상조직에서도 발현되며 병변 과정에서 그 발현 정도가 증가되어 암촉진 과정에서 일어나 는 피부염증에서 중요한 역할을 한다(29).

본 실험에서 고려엉겅퀴 추출물에 대한 COX-2, iNOS, IL-6, TNF- $a$ 의 발현정도를 측정한 결과는 Fig. 4 와 같다. COX-2는 LPS 단독 처리군에서 대조군보다 약 5 배 증가하 였으며 indomethacin 처리군과 고려엉겅퀴 처리군은 LPS 단독 처리군에 비하여 각각 $36 \%, 55 \%$ 정도로 발현이 감소 하였다. iNOS는 LPS 단독 처리군에서 대조군보다 약 7 배 증가하였으며 indomethacin 처리군과 고려엉겅퀴 처리군

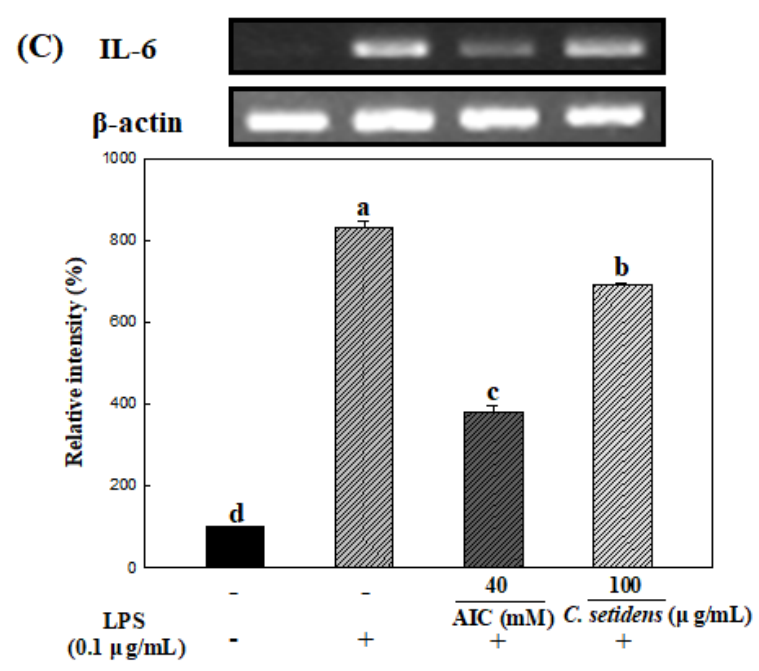

(D)

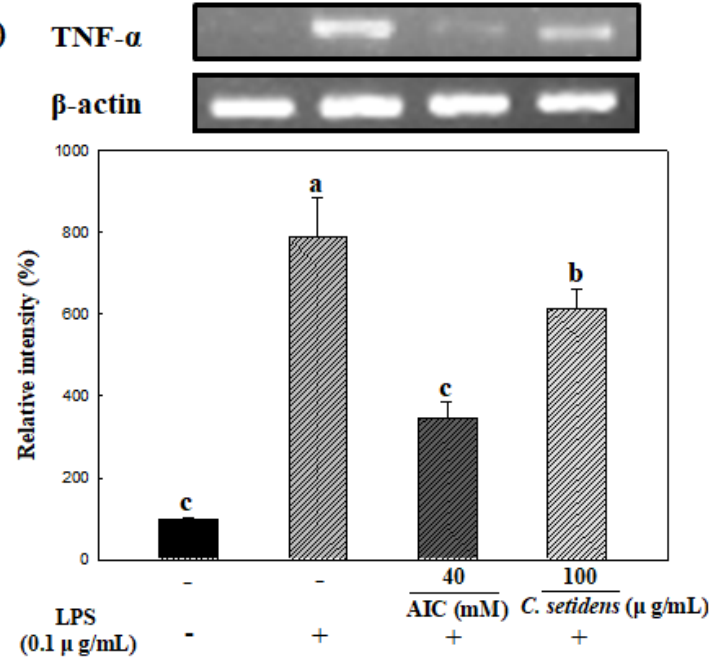

(A)

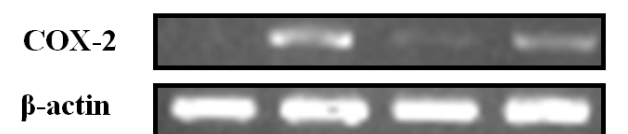

(B)

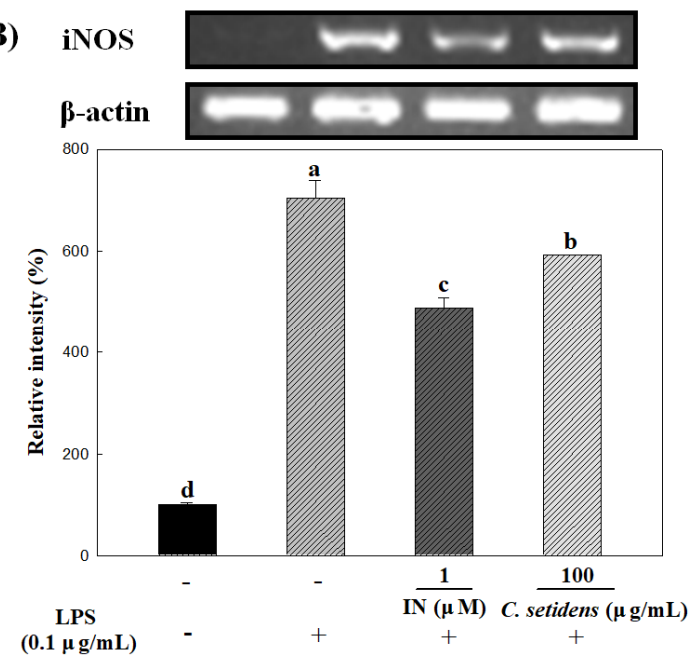

Fig. 4. C. setidens inhibits the mRNA expression of inflammatory mediators in RAW 264.7 cells.

IN:indomethacin, AIC:AICAR.

The cells were treated with $1 \mu \mathrm{M}$ indomethacin, $40 \mathrm{mM}$ AICAR, $100 \mu \mathrm{g} / \mathrm{mL}$ of $C$. setidens extract and $0.1 \mu \mathrm{g} / \mathrm{mL}$ LPS for $24 \mathrm{~h}$. The mRNA expression of (A) COX-2, (B) iNOS, (C) IL-6, (D) TNF-a was measured by polymerase chain reaction. Expression levels were densitometrically quantified with normalization to the control. Each value represents mean $\pm \mathrm{SD}(\mathrm{n}=3)$. ${ }^{\text {a-d }}$ Means with different letters are significantly different at $\mathrm{p}<0.05$ by Duncan's multiple range test. 
은 LPS 처리군에 비하여 각각 $69 \%, 84 \%$ 정도로 발현이 감소하였다. IL-6는 LPS 단독 처리군에서 대조군보다 약 8 배 증가하였으며 AICAR 처리군과 고려엉겅퀴 처리군은 LPS 처리군에 비하여 각각 $46 \%, 83 \%$ 정도로 발현이 감소하 였다. TNF- $a$ 는 LPS 단독 처리군에서 대조군보다 약 8 배 증가하였으며 AICAR 처리군과 고려엉겅퀴 처리군은 LPS 처리군에 비하여 각각 $44 \%, 78 \%$ 정도로 발현이 감소하였 다. 실험결과, COX-2, iNOS, IL-6, TNF- $a$ 에서 모두 LPS 단독 처리군에서는 발현양이 매우 증가하였으며 고려엉겅 퀴 추출물을 처리한 실험군과 양성대조군을 처리한 실험군 에서는 억제효과가 나타난 것을 통계적으로 확인하였다. 이는 LPS에 의한 염증 유도 시 COX-2, iNOS, TNF- $a$ 등의 생산이 증가된다는 Lee 등(30)의 논문의 보고와 일치한다. 본 연구에서 고려엉겅퀴 추출물이 NO 생성을 저해한 실험 결과로 볼 때, 고려엉겅퀴 추출물에 의한 $\mathrm{NO}$ 생성 저해가 전사단계에서 $\mathrm{iNOS}$ 와 COX-2 유전자의 발현을 억제함으로 써 일어남을 시사한다. 이와 같은 실험결과로 볼 때, 고려엉 겅퀴 추출물은 염증반응 관련 cytokine들을 효과적으로 저 해하는 것으로 확인되어 $\mathrm{mRNA}$ 조절 기능을 통해 염증성 질환의 치료에 유의할 것으로 사료된다.

\section{요 약}

본 연구에서는 고려엉겅퀴를 건강기능식품 소재로 활용 시 기초자료를 제공하고자 고려엉겅퀴의 항염증 효과를 규명하고자 수행되었다. 고려엉겅퀴 추출물을 이용하여 아 질산염 소거능, XTT 세포독성평가, NO 생성 저해능 평가, RT-PCR을 진행하였다. 고려엉겅퀴 추출물의 아질산염 소 거능 측정 실험 결과, 양성대조군으로 사용된 $\mathrm{BHA}$ 처리 실험군과 마찬가지로 농도 유의적으로 아질산염 소거능이 증가하는 것을 확인하였다. XTT 세포독성 평가 실험 결과, 고려엉겅퀴 추출물 $50,100,200 \mathrm{\mu g} / \mathrm{mL}$ 의 농도에서 독성이 없음을 확인하고 이어지는 항염증 효과를 측정하는 실험에 사용하였다. NO 생성 저해능 평가 실험 결과, 양성대조군으 로 사용된 indomethacin과 마찬가지로 고려엉겅퀴 추출물 $50,100,200 \mu \mathrm{g} / \mathrm{mL}$ 에서 농도 유의적으로 염증반응 매개물 질인 $\mathrm{NO}$ 의 생성량이 감소되는 것을 확인할 수 있었다. 또한 RT-PCR 실험 결과, $\mathrm{COX}-2$ 와 $\mathrm{iNOS}$ 은 양성대조군으로 사 용된 indomethacin 처리 실험군과 마찬가지로 고려엉겅퀴 처리군에서 생성 량이 감소된 것을 확인 할 수 있었고, IL-6 와 TNF- $a$ 의 경우에서도 양성대조군으로 사용된 AICAR 처리 실험군과 같이 고려엉겅퀴 처리군에서 생성이 억제된 것을 확인 할 수 있었다. 이러한 연구결과로 볼 때 고려엉겅 퀴 추출물이 대식세포에 의해 생성되는 염증반응의 매개물 질인 $\mathrm{NO}$ 의 생성을 억제하고, 염증반응 관련 cytokine들의 생성도 억제함에 따라 염증반응을 완화시키는데 도움을
줄 것으로 판단된다. 따라서 고려엉겅퀴가 천연 항염증활 성과 아질산염 소거능을 갖는 제품 개발에 있어서 유용한 식물자원 원료로써 사용될 수 있을 것으로 사료된다.

\section{감사의 글}

본 논문은 2017년도 한국연구재단 재원(NRF2017R1D1A3B06028469) 및 2018년 정부(교육부)의 재원 으로 한국 연구재단의 지원(한국연구재단-2018-미래기초 과학핵심리더양성사업/글로벌박사양성사업)을 받아 수행 된 연구로 이에 감사드립니다.

\section{References}

1. Christiansen LN, Tompkin PB, Shaparis AB, Kueper TV, Johnston RW, Kautter DA, Kolari OJ (1974) Effect of sodium nitrite on toxin production by Chlostridium botulimum in bacon. Appl Microbiol, 27, 733-737

2. Kang YH, Park YK, Lee GD (1996) The nitrite scavenging and electron donating ability of phenolic compounds. Korean J Food Sci Technol, 28, 232-239

3. Jin Q, Park JR, Kim JB, Cha MH (1999) Physiological activity of zizyphus jujuba leaf extracts. J Korean Soc Food Sci Nutr, 28, 593-598

4. Wang Y, Vodovotz Y, Kim PK, Zamora R, Billiar TR (2002) Mechanisms of hepatoprotection by nitric oxide. Ann N Y Acad Sci, 962, 415-422

5. Hippeli S, Elstner EF (1999) Inhibition of biochemical model reactions for inflammatory processes by plant extracts: a review on recent developments. Free Radical Res, 31, 81-87

6. McCartney-Francis N, Allen JB, Mizel DE, Albina JE, Xie QW, Nathan CF, Wahl SM (1993) Suppression of arthritis by an inhibitor of nitric oxide synthase. J Exp Med, 178, 749-754

7. Nathan C (1992) Nitric oxide as a secretory product of mammalian cells. FASEB J, 6, 3051-3064

8. Yun HY, Dawson VL, Dawson TM (1996) Neurobiology of nitric oxide. Crit Rev Neurobiol, 10, 291-316

9. Masferrer JL, Zweifel BS, Manning PT, Hauser SD, Leahy KM, Smith WG, Isakson PC, Seibert K (1994) Selective inhibition of inducible cyclooxygenase 2 in vivo is antiinflammatory and nonulcerogenic. Proc Natl Acad Sci U S A, 91, 3228-3232

10. Beutler B, Cerami A (1989) The biology of 
cachectin/TNF-a primary mediator of the host response. Annu Rev Immunol, 7, 625-655

11. Lee SH, Jin YS, Heo SI, Shim TH, Sa JH, Choi DS, Wang MH (2006) Composition analysis and antioxidative activity from different organs of Cirsium setidens Nakai. Korean J Food Sci Technol, 38, 571-576

12. Ishida H, Umino T, Tsuji K, Kosuge T (1989) Studies on the anti-hemorrhagic substances in herbs classified as hemostatics in Chinese medicine. X. On hemostatic activities of the parched herbs for hemostatics. Yakugaku Zasshi, 109, 179-183

13. Kim EH, Chung JY (2016) Protective effects of Cirsium setidens ethanolic extracts against alcoholic fatty liver injury in rats. J Nutr Health, 49, 420-428

14. Cho BY, Lee JH, Choi SI, Jung TD, Choi SH, Ra MJ, Kim SY, Kang IJ, Han KC, Lee OH (2017) Changes in Antioxidant and Antiobesity Activities of Cirsium setidens Nakai Ethanolic Extract Depending on Different Harvest Time. J Food Hyg Saf, 32, 234-242

15. Kim YH, Bae DB, Park SO, Lee SJ, Cho OH, Lee OH (2013) Method validation for the determination of eleutherosides and $\beta$-glucan in Acanthopanax koreanum. J Korean Soc Food Sci Nutr, 42, 1419-1425

16. Cho BY, Lee JH, Ra MJ, Kim SY, Kang IJ, Han KC, Lee OH (2016) Analysis of Pectolinarin Content and Antioxidant activity in Cirsium setidens Nakai by Cultivars. J Food Hyg Saf, 31, 210-215

17. Lee JH, Cho YH, Cho BY, Ra MJ, Kim SY, Kang IJ, Han KC, Lee OH (2016) Stability of Ethanolic Extract from Cirsium setidens Nakai. J Food Hyg Saf, 31, 304-309

18. Kato H, Lee IE, Chuyen NV, Kim SB, Hayase F (1987) Inhibition of nitrosamine formation by nondialyzable melanoidins. Agr Biol Chem, 51, 1333-1338

19. Kim DJ, Jung JH, Kim SG, Lee HK, Lee SK, Hong HD, Lee BY, Lee OH (2011) Antioxidants and anti-obesity activities of hot water and ethanolic extracts from Cheonnyuncho (Opuntia humifusa). Korean J Food Preserv, 18, 366-373

20. Bae IK, Min HY, Han AR, Seo EK, Lee SK (2005) Suppression of lipopolysaccharide-induced expression of inducible nitric oxide synthase by brazilin in RAW 264.7 macrophage cells. Eur J Pharmacol, 513, 237-242

21. Kim DB, Shin GH, Lee JS, Lee OH, Park IJ, Cho JH (2014) Antioxidant and nitrite scavenging activities of Acanthopanax senticosus extract fermented with different mushroom mycelia. Korean J Food Sci Technol, 46,
205-21

22. Lee BH, Baik DS, Yun SU, Shin JM, Kim JH, Yun SY, Kim BH, Kim SB, Shin JE, Song IH (2007) Peripheral Nitric Oxide activity in patients with liver cirrhosis. Korean J Med, 7, 251-257

23. Soe JS, Lee TH, Lee SM, Lee SE, Seong NS, Kim J (2009) Inhibitory effects of methanolic extracts of medicinal plants on nitric oxide production in activated macrophage RAW 264.7 cells. Korean J Medicnal Crop Sci, 17, 173-178

24. Kim JY, Jung KS, Jeong HG (2004) Suppressive effects of the kahweol and cafestol on cyclooxygenase-2 expression in macrophages. FEBS Lett, 569, 321-326

25. Chun KS, Surh YJ (2004) Signal transduction pathways regulating cyclooxygenase-2 expression: potential molecular targets for chemoprevention. Biochem Pharmacol, 68, 1089-1100

26. Kim RG, Shin KM, Chun SK, Ji SY, Seo SH, Park HJ, Choi JW, Lee KT (2002) In vitro antiinflammatory activity of the essential oil from ligularia fischeri var. spiciformis in murine macrophage RAW 264.7 cells. Yakhak Hoechi, 46, 343-347

27. Tezuka Y, Irikawa S, Kaneko T, Banskota AH, Nagaoka T, Xiong Q, Hase K, Kadota S (2001) Screening of chinese herbal drug extracts for inhibitory activity on nitric oxide production and identification of an active compound of zanthoxylum bugeanum. J Ethnopharmacol, 77, 209-217

28. Delgado AV, McManus AT, Chambers JP (2003) Production of tumor necrosis factor-alpha, interleukin 1-beta, interleukin 2, and interleukin 6 by rat leukocyte subpopulations after exposure to substance P. Neuro, 37, 355-361

29. Pociot F, Briant L, Jongeneel CV, Mölvig J, Worsaae H, Abbal M, Thomsen M, Nerup J, Cambon-Thomsen A (1993) Association of tumor necrosis factor (TNF) and class II major histocompatibility complex alleles with the secretion of TNF- $\alpha$ and TNF- $\beta$ by human mononuclear cells: a possible link to insulin-dependent diabetes mellitus. Eur J Immunol, 23, 224-231

30. Lee ES, Ju HK, Moon TC, Lee E, Jahng Y, Lee SH, Son JK, Baek SH, Chang HW (2004) Inhibition of nitric oxide and tumor necrosis factor- $a$ (TNF-a) production by prepenone compound through blockade of nuclear factor (NF)- $\kappa \mathrm{B}$ activation in cultured murine macrophages. Biol Pharm Bull, 27, 617-620 